\title{
A Study on the Influence Factors of Short-Term International Capital Flows-The Evidence from Emerging Markets
}

\author{
Huiqin Ma \\ School of Economics, Jinan University, Guangzhou, China \\ Email: hqma1227@163.com
}

How to cite this paper: Ma, H.Q. (2018) A Study on the Influence Factors of Short-Term International Capital Flows-The Evidence from Emerging Markets. Modern Econo$m y$, 9, 758-774.

https://doi.org/10.4236/me.2018.94050

Received: March 23, 2018

Accepted: April 23, 2018

Published: April 26, 2018

Copyright $\odot 2018$ by author and Scientific Research Publishing Inc. This work is licensed under the Creative Commons Attribution International License (CC BY 4.0).

http://creativecommons.org/licenses/by/4.0/

\section{c) (i) Open Access}

\begin{abstract}
This paper conducts an empirical analysis based on the balanced panel data of 18 emerging market economies between Q1, 2005 and Q3, 2017 to identify the influence factors of short-term international capital and discuss their time-varying characteristics. The system GMM model shows that short-term international capital is negatively correlated with the VIX (Volatility Index) and US real GDP growth rate, and is positively correlated with the appreciation of emerging markets' currencies. The TVP-VAR model shows that short-term international capital has positive impulse response to its own changes, appearing "herd effect", and has the largest impulse response to US GDP growth, VIX, US dollar appreciation and itself within two quarters, which are all consistent with the variability of itself. What's more, the VIX exhibits obvious time-varying characteristics. The financial crisis expands the influence of VIX and the US GDP growth rate, and the first round of QE amplifies the influence of VIX.
\end{abstract}

\section{Keywords}

Short-Term International Capital Flow, VIX, Exchange Rate

\section{Introduction}

Since the $21^{\text {st }}$ century, the development of internet technology has greatly enriched and improved the channels and efficiency of international capital circulation, but it has also led the development of international capital flows to the result of more short-term and high-frequency. Although measured by the absolute scale, international capital flow mainly occurs in developed countries; its importance of the financial stability of emerging markets is still self-evident. 
According to IFF (Institute of International Finance) statistical data, the scale of international capital that flowed into emerging markets in 2007 was once as high as 1.24 trillion US dollars, and in 2008, it was rapidly reduced to 0.67 trillion US dollars. Since then, the Fed has implemented QE, the federal interest rate has remained at a low level, and the currency issuance has been increased, prompting a large influx of international capital flowed into emerging markets. In May 2013, the Federal Reserve proposed that it would gradually reduce until it finally withdrew from the asset purchasing program (Tapering Talk), and the global bond market and stock market fluctuated dramatically. In the second half of the year, the amount of international capital outflow of emerging markets reached 60 billion US dollars. In 2017, the global economy showed a mild recovery trend, the non-resident combined capital that flowed into emerging markets for the full year reached 235 billion US dollars, setting a new record for the past three years. Therefore, in the emerging markets where large-scale international capital inflows exist before the financial crisis, there is a widespread problem of sharply reducing in capital inflows or increasing sharply in capital outflows during the crisis, and in different time periods, the influence factors are different. It is obvious that these large-scale, high-frequency, multi-channel capital flows would have a huge impact on the healthy development of a country's economy and seriously affect the stable and orderly operation of the global economy. ${ }^{1}$

This paper takes the interest rate, real GDP growth rate, change in the exchange rate, and financial system development in emerging markets, the interest rate and real GDP growth rate in developed countries, and the VIX as the main research direction, selects the quarterly data of 18 emerging market economies between the first quarter of 2005 and the third quarter of 2017 to build balanced panel data and identify the influence factors of short-term international capital flows in emerging market economies through the random effects model and system generalized method of moments (GMM). The time-varying parameter vector autoregression (TVP-VAR) is also used to explore the time-varying characteristics of major influence factors, and tries to discuss the time-varying characteristics of relevant external policies in order to provide a reference for monetary authorities to establish early-warning mechanisms and formulate policy tools, and also to provide the short-term international capital flows theories with the evidence from emerging markets.

This paper can be divided into four parts. The second part is the literature review, which summarizes the related research conclusions of short-term international capital flows. The third part is the empirical research, which can be further divided into the identification of influence factors and the analysis of time-varying characteristics, and then the paper attempts to discuss the impact of major changes in external policies. The fourth part is policy recommendations.

The innovation of this paper lies in the richness of sample data and the adop-

${ }^{1}$ Data Source: The related data in this paragraph are quoted from IFF (Institute of International Finance), whose official website is https://www.iif.com/. 
tion of the TVP-VAR model. Firstly, there are few researches based on the balanced panel data from emerging market countries. Secondly, due to the influence of social progress and institutional changes, it is difficult to keep the variance of the $\mu$ and the variable parameters constant. This paper constructs a TVP-VAR model that can capture the time-varying characteristics of the parameters and overcome the above problem to a certain degree. However, limited by the availability of data, the complexity of short-term international capitals, and the limitations of TVP-VAR models, there may be problems with insufficient variables.

\section{Literature Review}

When the US subprime mortgage crisis broke out in 2008, international capital flows fluctuated dramatically, which attracted wide attention from scholars and supervisors both at home and abroad. A study by Osan Sula, Thomas D. Willett (2009) [1] pointed out that the characteristics and trends of international capital flow under normal economic conditions and crisis were different and almost unrelated. Kristin J. Forbes, Francis E. Warnock (2012) [2] divided international capital flows into four stages: surges, stops, flights, and retrenchment. During the surges phase, international capital inflows increased significantly; during the stops phase, total international capital inflows decreased significantly; during the flight phase, total international capital outflows increased significantly; during the retrenchment phase, total international capital outflows decreased significantly. Manuel R. Agosin, Franklin Huaita (2012) [3] pointed out that the surge of international capital indicated that the phenomenon of international capital stop was approaching, and the longer the surge continued, the greater the probability the arrival of the stop.

Research by Miranda-Agrippino \& Rey (2015) [4] pointed out that a potential global factor was an important cause of global capital flows and it was clearly stated that this global factor was driven by risk aversion, but no quantitative considerations conduct in the paper. Recently, Cerutti, Claessens, and Rose (2017) [5] pointed out that the global potential factors driven by the degree of risk aversion had explained more than $25 \%$ of the changes in international capital flows. At the same time, a large number of scholars continued to use the "push-pull" theory to conduct research. Marcel Fratzscher (2012) [6] pointed out that the pushing factor was the main influence factor of international capital flow during the financial crisis, and the pulling factor was the main influence factor of international capital flow after the financial crisis. Shaghil Ahmed, Andrei Zlate (2015) [7] pointed out that differences in economic growth rates and interest rates between emerging market economies and developed economies were important determinants of net international capital flows; changes in interest rates during the financial crisis have led to the great changes of net international capital flows.

Most studies on international capital flows in China have focused on analyz- 
ing their impact mechanisms. Ju, J.D. and Wei (2010) [8] proposed that countries with higher levels of financial development were more inclined to conduct direct international investment in other countries and attract financial capital to flow into their own countries. Li Kunwang and Liu Jian (2012) [9] proposed that financial development can promote equity investment decision-making and investment scale, and have an expansion effect on bilateral equity flows. Chen Jianqi and Zhang Yuan (2013) [10] pointed out that quantitative easing policies can promote the flow of capital into emerging markets. Zhang Huaiqing (2013) [11] and Yi Xianrong (2014) [12] pointed out that the United States withdrawing from QE would attract cross-border capital back to developed economies and bring adverse impact to emerging markets.

Zheng Xuan (2015) [13] proposed that there would be a sudden disruption of international capital flows in the short-term, and the international capital would flow from developed economies to emerging market economies in the middle to long-term. At the same time, some scholars focused on discussing the classification of major economies in the world. Xiang Weixing and Wang Da (2011) [14] believed that the impact of international capital flows which caused by the financial crisis has weakened one by one among Eastern Europe, Latin America, and East Asian countries. Zhang Ming (2014) [15] believed that the economic growth rate of emerging markets and the change rate of local currency exchange rate were important pulling factors while global risk appetite and US economic growth rate were important pushing factors. Zhang Guangting (2016) [16] believed that infectious agents were the primary factors affecting cross-border capital flows in emerging markets, and the factors affecting the cross-border capital flows after the crisis were more complex, suggesting that the hidden trouble linkages in the financial markets after the crisis has been strengthened.

The relevant empirical methods include VAR, GMM, OLS, static panel, dynamic panel, GARCH model, Probit model, etc., supplemented by Granger causality test, ADF test and so on. Ma Yu and Du Meng (2013) [17] conducts empirical research through the GMM method and the result shows that the US money supply, China's interest rate level, and exchange rate changes are positively related to short-term capital flows, and inflation and investment risk levels are negatively correlated with short-term capital flows. Wu Lihua and Fu Guangmin (2014) [18] point out that, based on TVP-SV-VAR, exchange rate appreciation and international capital inflow can promote each other, and the impact of short-term capital inflow on the stock price is not certain. The empirical results of Dong Youde and Xie Qinyi(2015) [19] who apply the GARCH model and the Probit model shows that global market fluctuations, effective exchange rate fluctuations, and global liquidity have a significant impact on international capital flows and play different roles in different stages. Zhao Xinquan and Liu Wenge (2016) [20] point out that financial development is an important factor that affects the flow of international capital, and it has different effects on developed economies and emerging markets. 
Foreign scholars' researches on short-term international capital flows are earlier than those of domestic scholars, and most of domestic scholars extend and explore short-term international capital flows by following the logic of foreign research. As a whole, there is still room for improvement in the research in the following aspects. Firstly, no agreement has been reached on the factors that affect the flow of international capital. The agreement that global panic is an important influence factor of short-term international capital flows has been gradually reached, but there is little research on how the influence factors evolve under different economic status. Secondly, there are few studies on the time-varying characteristics of variables. The factors that influence the short-term international capital flow in emerging markets are not static, but change all the time. Therefore, we need to consider the time-varying characteristics of variables, and currently, related research is rare in China. Finally, a large number of scholars in China have focused on China's short-term capital flows, few studies have looked at the larger and weaker groups in emerging markets.

\section{Identification of Influence Factors}

The data in this paper come from IMF's IFS database, Bloomberg database, Wind database, and CEIC database. The samples are panel data consist of 18 emerging market countries from Q1, 2005 to Q3, 2017, since this 12-year period includes financial crisis and can be normally considered as a whole economic cycle. The softwares used are EViews, STATA, and MATLAB. According to the IMF's criteria for the emerging market countries and the comprehensive consideration of data availability, the sample countries selected are China, Indonesia, Russia, India, Thailand, South Korea, Singapore, Hong Kong, Philippines, Malaysia, Sri Lanka, Vietnam, South Africa, Peru, Mexico, Ukraine, Chile, and Brazil.

Set the basic regression equation as:

$$
\begin{aligned}
s c f_{i t}= & \alpha+\beta_{1} g d p_{i t}+\beta_{2} i_{i t}+\beta_{3} e_{i t}+\beta_{4} u s g d p_{i t}+\beta_{5} u s i_{i t}+\beta_{6} v i x_{i t} \\
& +\beta_{7} f s d_{i t}+\ldots+v_{i}+u_{i t}
\end{aligned}
$$

$i$ denotes the country; $t$ denotes the time; $\alpha$ is the intercept term, $u$ is the random error term, and $V$ is the country's individual effect. Table 1 shows the name, symbol, interpretation, unit, and data source of each variable.

Table 2 shows the descriptive statistics of variables. Firstly, the short-term international capital flows in emerging markets have large standard deviation and large range, indicating that the volatility of the short-term capital is strong; secondly, economic fluctuations happen more often in the emerging markets under rapid development; thirdly, US dollar is appreciated in total during the sample time; fourthly, there is a large fluctuation in global market panic within the sample interval; finally, the market value of each economy's stock accounted for approximately $50 \%$ of the GDP in current quarter when they are translated linearly into annual data and it is quite different from the developed countries. In fact, even within emerging markets, the gap is also very large. 
Table 1. The meaning of variables and data sources.

\begin{tabular}{|c|c|c|c|c|}
\hline Variable Name & Symbol & Variable Interpretation & Unit & Data Sources \\
\hline $\begin{array}{l}\text { Short-Term International } \\
\text { Capital Flow Ratio }\end{array}$ & $\operatorname{scf}$ & $\begin{array}{c}\text { (Increase in Foreign Exchange Reserves - Trade Surplus - Foreign Direct } \\
\text { Investment)/Current Nominal GDP }\end{array}$ & $\%$ & $\begin{array}{l}\text { IMF's IFS database } \\
\text { CEIC database }\end{array}$ \\
\hline Emerging Market GDP & gdp & Real GDP Growth Rate in Emerging Market Countries & $\%$ & IMF's IFS database \\
\hline $\begin{array}{l}\text { Emerging Market Interest } \\
\text { Rates }\end{array}$ & i & $\begin{array}{l}\text { The overnight interbank rates of banks in emerging market countries, to } \\
\text { some extent, it can reflect the return on investment of the economy }\end{array}$ & $\%$ & IMF's IFS database \\
\hline $\begin{array}{l}\text { Change in the Exchange } \\
\text { Rate }\end{array}$ & $\mathrm{e}$ & $\begin{array}{l}\text { (The current average exchange rate/the average exchange rate of the } \\
\text { previous period }-1)^{\star} 100 \% \\
\text { emerging markets' currencies are priced in dollars, and a number greater } \\
\text { than zero indicates that the dollar has appreciated }\end{array}$ & $\%$ & CEIC database \\
\hline US Real GDP Growth & usgdp & Economic growth rates of advanced economies & $\%$ & IMF's IFS database \\
\hline US Federal Rate & usi & Interest rate in advanced economies & $\%$ & IMF's IFS database \\
\hline Volatility Index & VIX & $\begin{array}{l}\text { Reflect market risks and investor panic levels. The higher the index, the } \\
\text { more volatile the stock index changes, the higher the degree of investor } \\
\text { panic }\end{array}$ & $\%$ & Wind database \\
\hline $\begin{array}{l}\text { Financial System } \\
\text { Development Level }\end{array}$ & fsd & $\begin{array}{l}\text { The ratio of stock market value of emerging market to its current GDP. The } \\
\text { greater the value is, the higher the degree of financial system development is }\end{array}$ & $\%$ & $\begin{array}{l}\text { Bloomberg database, } \\
\text { IMF's IFS database }\end{array}$ \\
\hline
\end{tabular}

Data sources: IMF's IFS database, CEIC database, Bloomberg database, and Wind database.

Table 2. Descriptive statistical analysis of variables.

\begin{tabular}{ccccc}
\hline Variable & average value & Standard deviation & Min & Max \\
\hline scf & -4.480 & 11.07 & -77.17 & 47.81 \\
gdp & 4.490 & 4.250 & -19.59 & 33.41 \\
i & 5.620 & 4.530 & 0 & 33.88 \\
e & 0.360 & 5.320 & -25.40 & 42.24 \\
usgdp & 1.670 & 1.720 & -4.060 & 3.760 \\
usi & 1.340 & 1.840 & 0.0700 & 5.250 \\
VIX & 18.86 & 8.260 & 9.510 & 44.14 \\
fsd & 204.4 & 1084 & 0.120 & 6723 \\
\hline
\end{tabular}

Data sources: IMF's IFS database, Wind database, CEIC database, Bloomberg database, STATA.

\subsection{Identifying Influence Factors Based on the Random Effect Model}

Table 3 shows the results of panel unit root test. Firstly, the panel data are separately subjected to LLC test (unit root test with the same root) and Fisher-ADF test (unit root test with different root). Each variable rejects the original assumption at least at $1 \%$ level, which means that each variable is stable and can be directly applied to subsequent panel model estimates.

Table 4 shows the results of the fixed effect and the random effect model. Firstly, the F/Wald statistics for the fixed effect and the random effect indicates that both models are overall significant. However, the Hausman test shows that random effect model is efficient. The random effect model results show that 
Table 3. Panel unit root test results.

\begin{tabular}{ccc}
\hline Method & LLC & ADF-Fisher \\
\hline scf & $-10.1120^{* * *}$ & $240.4668^{* * *}$ \\
& $(0.0000)$ & $(0.0000)$ \\
gdp & $-8.1887^{* * *}$ & $133.7195^{* * *}$ \\
& $(0.0000)$ & $(0.0000)$ \\
i & $-2.6171^{* * *}$ & $63.6262^{* * *}$ \\
& $(0.0044)$ & $(0.0030)$ \\
e & $-12.9439^{* * *}$ & $317.6841^{* * *}$ \\
& $(0.0000)$ & $(0.0000)$ \\
usgdp & $-6.6247^{* * *}$ & $118.8887^{* * *}$ \\
& $(0.0000)$ & $(0.0000)$ \\
usi & $-2.3674^{* * *}$ & $70.3082^{* * *}$ \\
& $(0.0090)$ & $(0.0005)$ \\
VIX & $-4.3695^{* * *}$ & $78.5643 * * *$ \\
& $(0.0000)$ & $(0.0001)$ \\
fsd & $-5.3834^{* * *}$ & $105.6544^{* * *}$ \\
& $(0.0000)$ & $(0.0000)$ \\
\hline
\end{tabular}

$\mathrm{H} 0$ is the hypothesis that there exists one unit root; corresponding p-value is included in the brackets; ${ }^{*}, *$ and ${ }^{* * *}$ mean that it corresponded passed the $10 \%, 5 \%$, and $1 \%$ significance test.

Table 4. The fixed effect and the random effect model operation results.

\begin{tabular}{ccc}
\hline Model & Fixed effect & Random effect \\
\hline gdp & $0.23541^{* * *}$ & $0.23462^{* * *}$ \\
i & $(0.088)$ & $(0.087)$ \\
& 0.04264 & 0.07000 \\
e & $(0.106)$ & $(0.104)$ \\
& $-0.14857^{* * *}$ & $-0.14922^{* * *}$ \\
usgdp & $(0.052)$ & $(0.052)$ \\
& $-0.83300^{* * *}$ & $-0.83143^{* * *}$ \\
usi & $(0.210)$ & $(0.210)$ \\
& 0.18288 & 0.17851 \\
VIX & $(0.161)$ & $(0.161)$ \\
& $-0.16476^{* * *}$ & $-0.16467^{* * *}$ \\
fsd & $(0.042)$ & $(0.041)$ \\
& $0.00274^{* *}$ & $0.00239^{* *}$ \\
_cons & $(0.001)$ & $(0.001)$ \\
N & -0.09136 & -0.41492 \\
F/wald & $(1.348)$ & $(2.287)$ \\
P_value (F) & 918 & 918 \\
Hausman (p) & 6.65795 & 47.38 \\
\hline
\end{tabular}

The number in brackets is robust standard errors; ${ }^{*}{ }^{* *}$ and ${ }^{* * *}$ mean that it corresponded passed the $10 \%$, $5 \%$, and $1 \%$ significance test; random effects model and dynamic panel model are tested by Wald statistics. 
short-term international capital flows are positively related to US dollar appreciation, emerging markets' economic growth, and financial system development, and are negatively related to VIX and US economic growth. All above indicates that economic growth and financial system development can indeed attract capital inflows, exchange rate fluctuation is an important factor that affects capital flows, and the global panic index can be used as an important indicator of the capital flows.

\subsection{Identifying Influence Factors Based on the System GMM Model}

The random effects model cannot overcome the endogenous problems of variables. Hausman's test shows that the variables in the model do exist endogenously. This paper will draw on and apply the system GMM method for dynamic panel analysis to solve endogenous problems. The GMM method was originally proposed by Arellano and Bond (1991) [21]. Later, Arellano and Bover (1995) [22] improved the method and came up with the horizontal GMM estimation method, but under the limited sample, both estimation results are not ideal. In 1998, Blundell and Bond (2000) [23] proposed the system GMM method, which is applicable to the case of the limited number of samples, and the estimation result is more ideal.

Table 5 shows the results of GMM models. Firstly, The Abond-Ar (1) and Abond-Ar (2) tests show that there is a first-order autocorrelation in the residuals after the difference, but there is no second-order autocorrelation; Sargan test shows that the model does not have the problem of transition identification of instrumental variables. In summary, the system GMM method is effective. The system GMM shows that exchange rate fluctuations, US economic growth, and the VIX are always important factors affecting short-term international capital flows.

The first order lag of scf in the system GMM still passes the significance test at the $1 \%$ level, indicating that short-term capital flow has a certain "herd effect" or "herd mentality". Both the real GDP growth rate and the financial system development in emerging markets have not passed the $10 \%$ significance test in the system GMM, indicating that both of them can have a certain appeal to international capital in the short term. The emerging market interest rate is positively related in both models, and can pass the significance test at the $10 \%$ level under the system GMM, indicating that its attraction to capital inflows is long-term. Dollar appreciation, US economic growth, and VIX are all negatively related in both models, and all can pass the significance test at the $1 \%$ level. These three variables play a decisive role in international capital flows. Two interest rate variables neither passes the significance test, and this paper believes that this is tightly associated with the more vulnerable financial system and higher risk premium in emerging market economies. 
Table 5. GMM model estimation results.

\begin{tabular}{|c|c|}
\hline Model & System GMM \\
\hline L.scf & $\begin{array}{c}0.49485^{\star * *} \\
(0.096)\end{array}$ \\
\hline gdp & $\begin{array}{l}0.07643 \\
(0.131)\end{array}$ \\
\hline $\mathrm{r}$ & $\begin{array}{c}0.46685^{\star} \\
(0.243)\end{array}$ \\
\hline $\mathrm{e}$ & $\begin{array}{c}-0.26352^{\star * *} \\
(0.100)\end{array}$ \\
\hline usgdp & $\begin{array}{c}-0.93589^{* * *} \\
(0.357)\end{array}$ \\
\hline usi & $\begin{array}{c}0.05852 \\
(0.218)\end{array}$ \\
\hline VIX & $\begin{array}{c}-0.18442^{\star * \star} \\
(0.044)\end{array}$ \\
\hline fsd & $\begin{array}{l}0.00027 \\
(0.000)\end{array}$ \\
\hline _cons & $\begin{array}{c}-0.03980 \\
(1.381)\end{array}$ \\
\hline Abond-Ar (1) ( $\mathrm{p}$ value) & 0.012 \\
\hline Abond-Ar (2) ( $\mathrm{p}$ value) & 0.222 \\
\hline Sargan (p value) & 0.186 \\
\hline
\end{tabular}

The number in brackets is robust standard errors; ${ }^{*}{ }^{* *}$ and ${ }^{* * *}$ mean that it corresponded passed the $10 \%$, $5 \%$ and $1 \%$ significance test; random effects model and dynamic panel model are tested by Wald statistics.

\subsection{Time-Varying Characteristics Analysis Based on TVP-VAR Model}

One common assumption of VAR model is that the variance of coefficients and error terms is fixed, but it is difficult to achieve in real life. This paper will use the parameter-variable TVP-VAR model proposed by Cogley \& Sargent (2001) [24], Lubik \& Schorfheide (2004) [25], and Giorgio E. Primiceri (2005) [26], and the parameters are estimated by MCMC (Markov Chain Monte Carlo) method. A priori probability density function is set for the covariance matrix of the parameter, and the posterior distribution is obtained by using the MCMC method. The selected variables are the ratio of average short-term capital flows to current GDP, average exchange rate fluctuations, usgdp and VIX. The MATLAB package of Professor Nakajima [27] [28] is used.

Firstly, referring to the AIC principle, the TVP-VAR model with one-order lag is chosen. Suppose that

$$
\mu_{a_{0}}=\mu_{\beta_{0}}=\mu_{h_{0}}=0, \sum_{a_{0}}=\sum_{\beta_{0}}=\sum_{h_{0}}=10 \times I
$$


the prior distribution of the covariance matrix is subject to

$$
\left(\sum_{\beta}\right)_{i}^{-2} \sim \operatorname{Gamma}(40,0.02),\left(\sum_{\alpha}\right)_{i}^{-2} \sim \operatorname{Gamma}(4,0.02),\left(\sum_{h}\right)_{i}^{-2} \sim \operatorname{Gamma}(4,0.02)
$$

and using MCMC to extract samples as $M=10,000$.

According to Table 6 which is the MCMC estimation results, the Geweke values of all the parameters fall within the $95 \%$ confidence interval, and the original hypothesis cannot be rejected (converging on the posterior interval). The maximum invalidity factor is 22.13 , which means that at least $10,000 / 23=$ 435 irrelevant samples are available, and it is sufficient for the posterior inference of the model. Figure 1 which is the simulation reference map of the MCMC model shows that the autocorrelation of the sample is rapidly declining and the sample path is relatively stable. The posterior distribution density function is relatively ideal.

Table 6. Analysis of MCMC estimation results.

\begin{tabular}{ccccccc}
\hline Parameter & mean deviation & Standard & 95\% confidence & interval & $\begin{array}{c}\text { Geweke } \\
\text { value }\end{array}$ & $\begin{array}{c}\text { Invalidity } \\
\text { factor }\end{array}$ \\
\hline sb1 & 0.0023 & 0.0003 & 0.0018 & 0.0029 & 0.343 & 3.31 \\
$\mathrm{sb} 2$ & 0.0023 & 0.0003 & 0.0018 & 0.0029 & 0.309 & 3.51 \\
$\mathrm{sa} 1$ & 0.0055 & 0.0015 & 0.0033 & 0.0092 & 0.496 & 13.63 \\
$\mathrm{sa} 2$ & 0.0055 & 0.0016 & 0.0034 & 0.0095 & 0.285 & 15.99 \\
$\mathrm{sh} 1$ & 0.0057 & 0.0018 & 0.0034 & 0.0102 & 0.613 & 22.13 \\
$\mathrm{sh} 2$ & 0.0055 & 0.0016 & 0.0033 & 0.0095 & 0.968 & 14.61 \\
\hline
\end{tabular}

Data sources: IMF's IFS database, CEIC database, Bloomberg database, and Wind database.
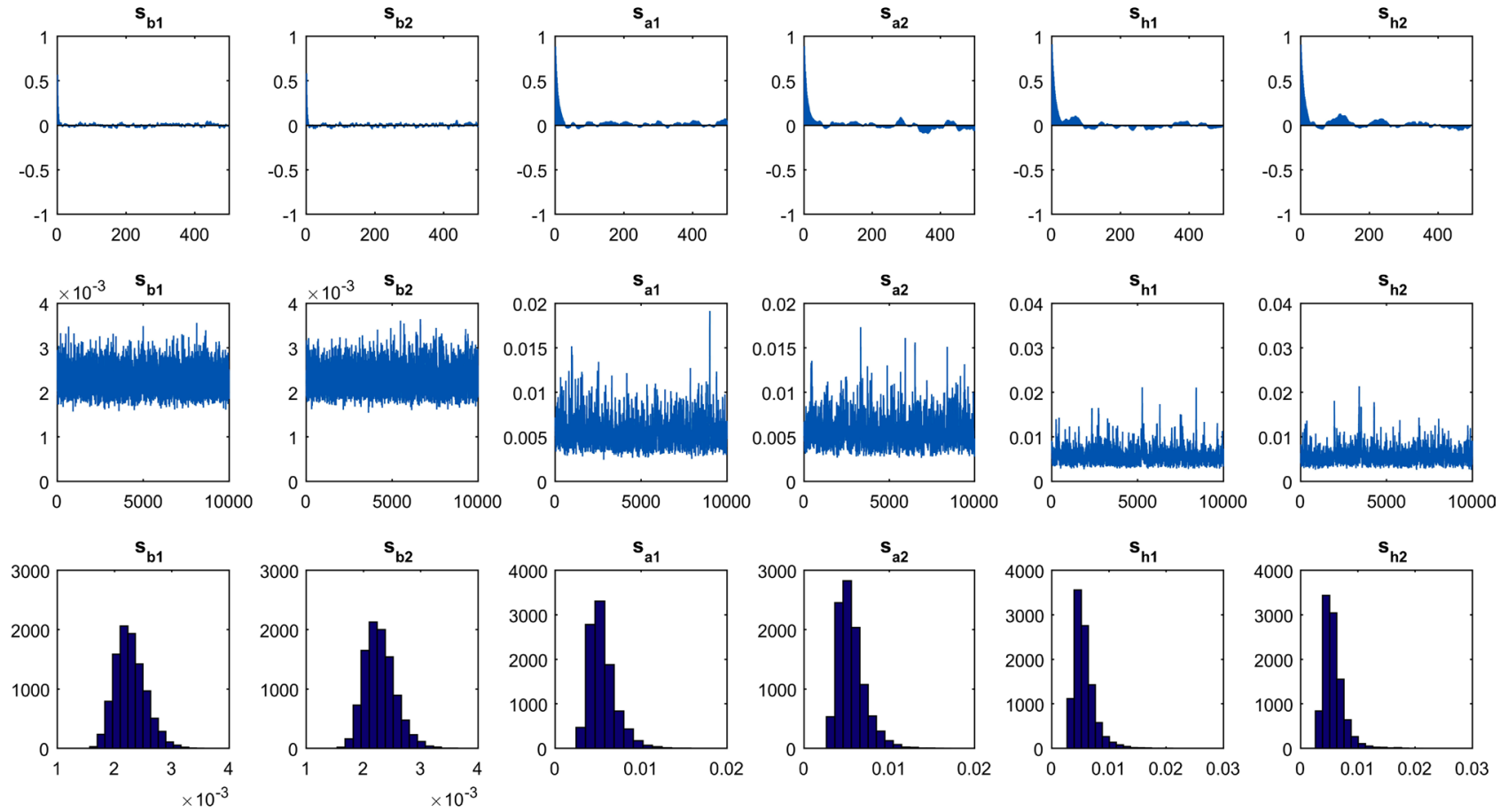

Figure 1. The results of MCMC simulation. 

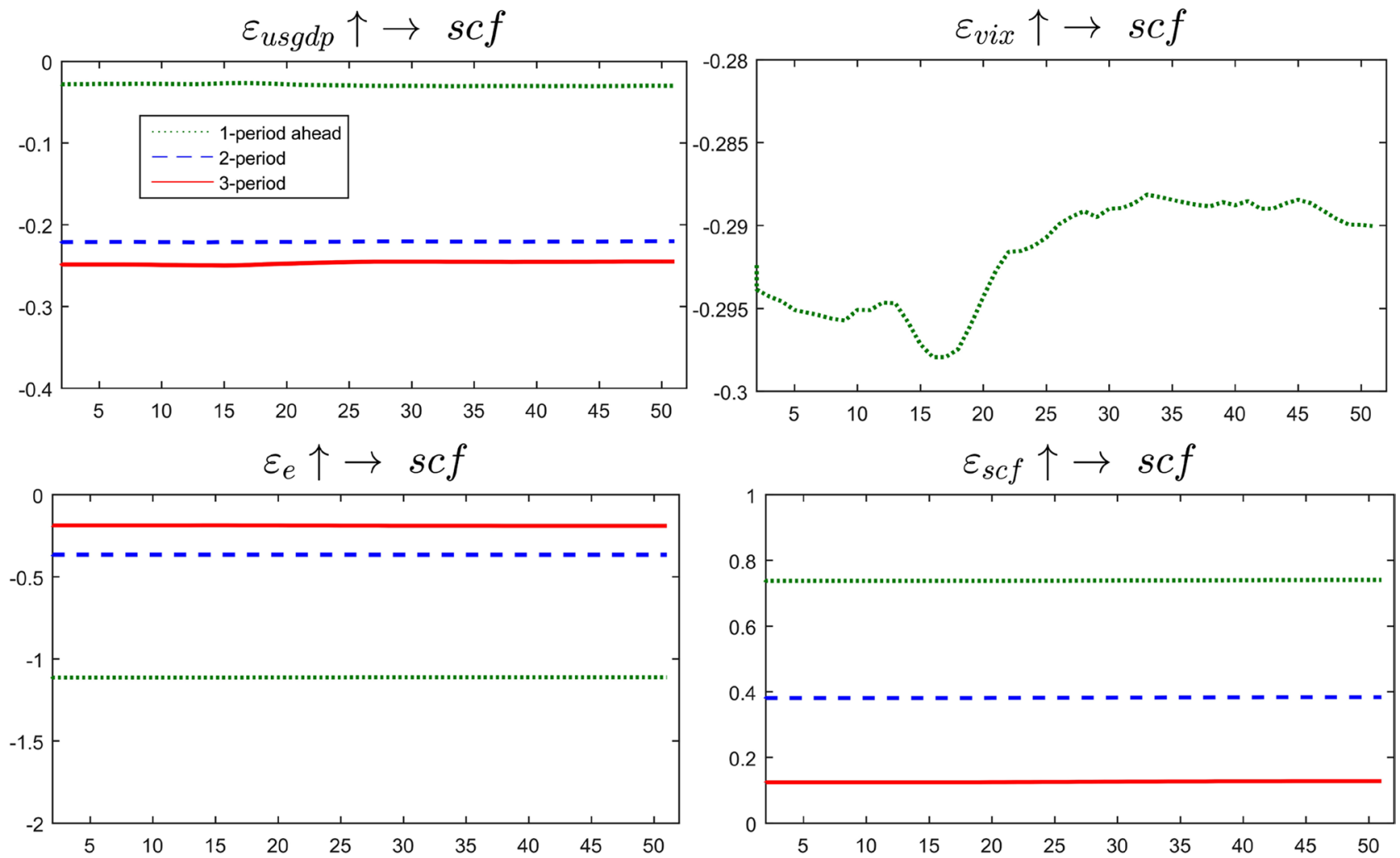

Figure 2. Equal interval impulse response curve of scf. 
and these time points corresponded to events such as the third round of the $\mathrm{QE}$ policy and the butterfly effect caused by the Fed's expected interest rate hike. It can be seen that the VIX shows a clear time-varying characteristic, when bad news appears in the market; the influence of the VIX is obviously strengthened.

The impulse response curve of scf to e shows that the magnitude of US dollar appreciation has a negative impact on short-term capital flows in emerging markets. The impulse response reaches a peak during the 1-period lag and reflects that the appreciation of the US dollar can effectively attract international short-term capital outflows from emerging markets, and this attraction is very violent within one quarter.

The impulse response curve of scf to its own impact reaches a peak during 1-period lag, followed by the 2-period lag and 3-period lag, indicating that the short-term capital flows in the emerging markets have a certain "herd effect" or "herd mentality". This phenomenon can only last for a short term, and the effect is most obvious within a quarter.

\subsubsection{Time Impulse Response of scf}

Firstly, determine the following three important time points for impact impulse response analysis: 1) $t=13(\mathrm{Q} 1,2008)$, the point that the global financial crisis erupted; 2) $t=7(Q 3,2006)$, the control group when the economy is under conditions; 3$) t=44(Q 4,2015)$, the Fed raised interest rates for the first time after the financial crisis, which means that $\mathrm{QE}$ is coming to an end and the economy is back to normal.

Figure 3 shows the results of time impulse response curve of scf. At different time point, the trend of the impact of usgdp, VIX, e, and scf on scf are basically the same. During the financial crisis $(t=13)$, scf has a greater impulse response to usgdp and VIX, indicating that the capital during the financial crisis is more likely to flow to developed economies such as the United States with stronger anti-risk capabilities, and that VIX's impact on scf is strengthened during financial crisis. However, the financial crisis does not change obviously the scf responses to the impact of e and scf itself, which shows that the influence of the change in the exchange rate and the "herd effect" of short-term international capital flows are relatively stable.

Secondly, the paper tries to explore the effect of the QE. The selected periods are $\mathrm{t}=15(\mathrm{Q} 3,2008), \mathrm{t}=23(\mathrm{Q} 3,2010)$, and $\mathrm{t}=31(\mathrm{Q} 3,2012)$, which corresponds to the period in which the first, second and third rounds of quantitative easing policies were implemented in the United States. Figure 4 shows the results of time impulse response curve of scf, too. The results show that the trend of the impact of various variables on scf at different time points is basically the same. The impulse response function curve of $t=15$ phase is located above the other two phases, indicating that the first round of QE amplifies the response of scf to VIX.

\subsection{Empirical Summary}

Both the random effects model and the system GMM method show that the 

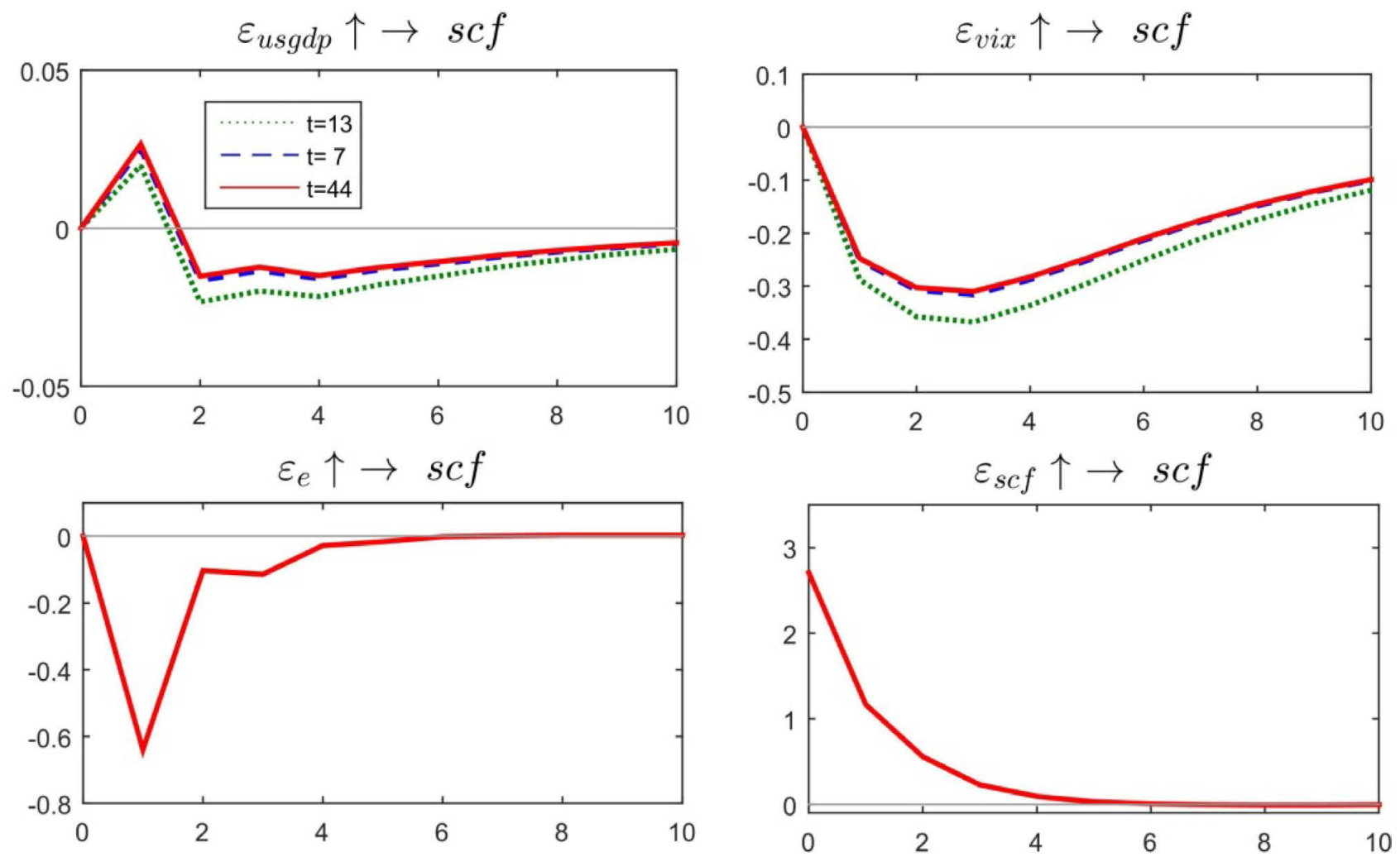

Figure 3. Time impulse response curve of scf.
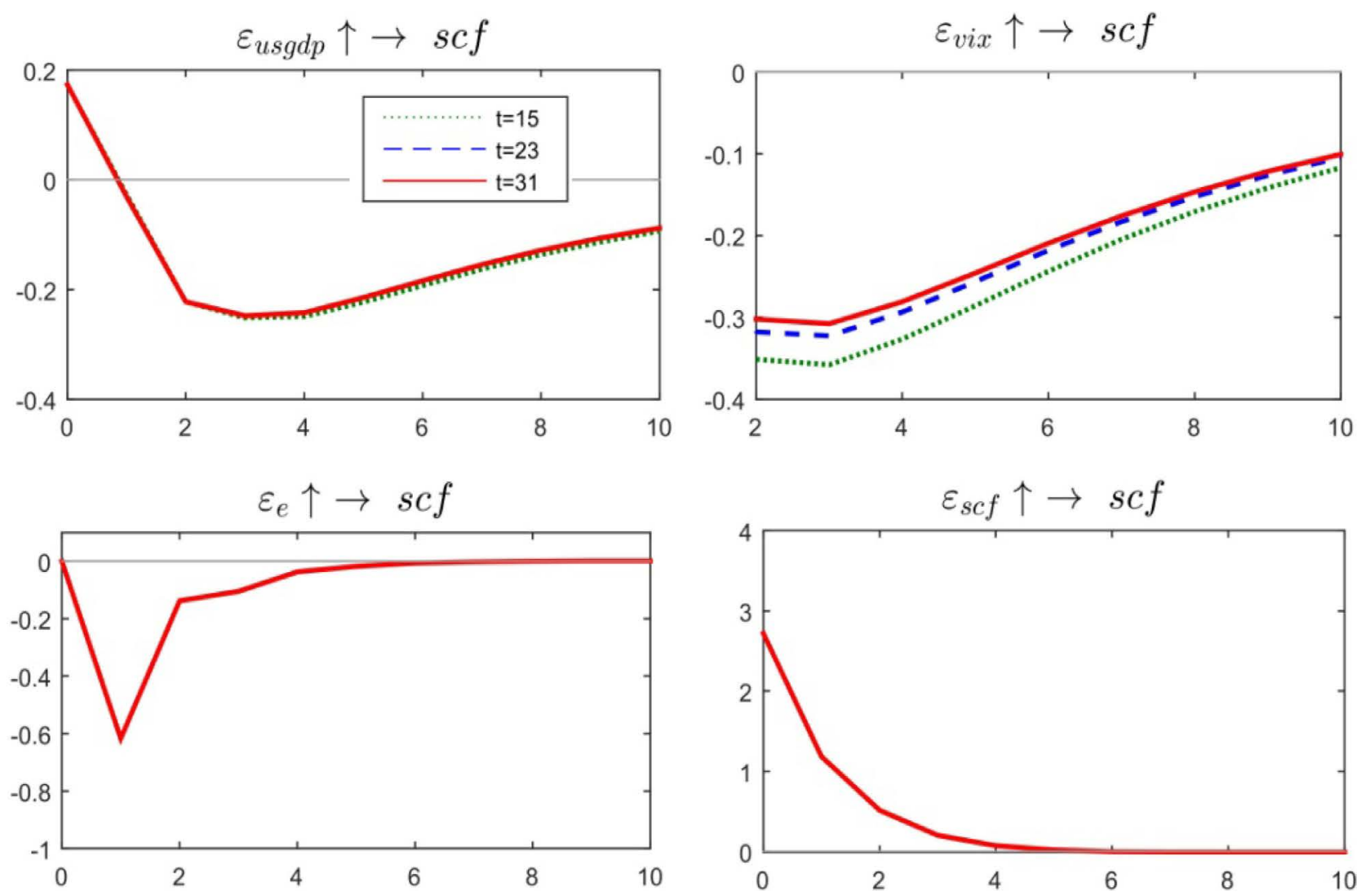

Figure 4. Time impulse response curve of scf. 
VIX, the growth rate of the US GDP, and change in the exchange rate are the three factors that have the greatest influence on short-term international capital flows in emerging markets. The VIX and the real GDP growth rate of the United States are negatively correlated to the short-term international capital flows to emerging market economies, and the magnitude of currency appreciation in each economy is positively related to short-term international capital flows. The TVP-VAR model shows that, firstly, scf has a certain self-enhancement ability; secondly, short-term international capital has the largest impulse response to the impact of US GDP growth, VIX, US dollar appreciation and itself within two quarters, which are all consistent with the variability of itself; thirdly, the VIX shows a clear time-varying characteristic, when bad news appears in the market, the influence of VIX shows a clear strengthening trend. At the same time, the financial crisis has expanded the influence of VIX and the US economic growth rate. The first round of QE amplifies the influence of global panic level.

\section{Policy Recommendations}

\subsection{Correctly Understand the Importance of Capital Supervision and Pay Attention to the Speed of International Capital Liberalization}

The supervision of capital flows can somehow balance stable exchange rate policies and independent monetary policies, and solve the "IMPOSSIBLE TRINITY" problem to a certain extent. However, there are also defects such as increasing cost pressure and distorting markets. Only when the "benefit" brought by regulation exceeds its "cost", it's valuable. The opening up of capital is a process in which the government has gradually liberalized the original capital supervision. After the 1980s, supervision showed a loose trend, however, after the 1990s, some countries strengthened international capital supervision. Taking Chile as an example, through implementing the Unremunerated Reserve Requirement (URR) policy in 1991, it did not prohibit international capital flows, raised domestic interest rates, and supplemented some capital control policies (defining minimum residence time for FDI and portfolio investment, etc.), the policy of gradual appreciation of the exchange rate, etc., and successfully improved their risk resilience and survived the economic crisis of the 1990s as a result. The case of Chile proves that the radical capital account liberalization policy is not desirable and capital account should be liberalized prudently.

\subsection{Combine "Price" and "Quantity" to Establish and Improve the Supervision Mechanism for Short-Term International Capital Flows}

At present, emerging markets generally adopt administrative intervention in the supervision of short-term international capital, and they are mostly focused on the control of "quantity", while the "price" control is slightly insufficient. In the future, on the basis of successful experience like Chile, we can use price management tools 
such as Tobin tax and Unremunerated Reserve Requirement (URR) to control the flow of capital. We can start from limiting the minimum residence time and also regulating the flowing channels to control the capital quantity, and strengthen the management and regulation of recurrent projects, capital projects, and even illegal inflow channels such as underground money houses.

\subsection{Establish a Dynamic Observation and Early-Warning Mechanism for Short-Term International Capital Flows}

On one hand, a high-frequency monitoring system for FDI, international payments, foreign exchange accounts and transactions, and foreign debt accounts should be established to provide accurate and timely capital flow for the supervisory authorities. On the other hand, strengthening cooperation among global economies and this can be led by a global organization such as the World Bank or the IMF, and establish a regular disclosure system and an international rating system for global short-term international capital positions. Each country can consider implementing cooperation supervision and international capital account management with major trade partners and close capital transaction countries.

\subsection{Develop Control and Prevention Policies Simultaneously, and Combine Exchange Rate Restructuring and Prudent Macro Policies}

The empirical results of this paper show that the exchange rate, GDP growth rate of developed economies, and VIX are important factors affecting short-term capital flows. Therefore, before large-scale capital account liberalization, emerging markets should realize exchange rate restructuring firstly to evade the systemic crisis caused by exchange rate fluctuations. At the same time, it also should be in conjunction with prudent macroeconomic policies in order to stabilize investors' risk aversion and alleviate the contraction of funds and the spillover effect of global capital flow in emerging market economies.

\section{References}

[1] Sula, O. and Willett, T.D. (2009) The Reversibility of Different Types of Capital Flows to Emerging Markets. Emerging Market Review, 10, 296-310. https://doi.org/10.1016/j.ememar.2009.08.001

[2] Forbes, K.J. and Warnock, F E. (2012) Capital Flow Waves: Surges, Stops, Flight, and Retrenchment. Journal of International Economics, 88, 235-251. https://doi.org/10.1016/j.jinteco.2012.03.006

[3] Agosin, M.R. and Huaita, F. (2012) Overreaction in Capital Flows to Emerging Markets: Booms and Sudden Stops. Journal of International Money \& Finance, 31, 1140-1155. https://doi.org/10.1016/j.jimonfin.2011.12.015

[4] Miranda-Agrippino, S. and Rey, H. (2015) World Asset Markets and the Global Financial Cycle. NBER Working Paper 2015: 21722.

[5] Cerutti, E., Claessens, S. and Rose, A. (2017) How Important Is the Global Financial Cycle? Evidence from Capital Flows, CEPR Discussion Paper 12075. 
[6] Fratzscher, M. (2012) Capital Controls and Foreign Exchange Policy. Centre for Economic Policy Research, London.

[7] Shaghil, A., Coulibaly, B. and Zlate, A. (2015) International Financial Spillovers to Emerging Market Economies: How Important Are Economic Fundamentals? Board of Governers of the Federal Reserve System. International Finance Discussion Papers, Number 1135.

[8] Ju, J.D. and Wei, S.J. (2010) Domestic Institutions and the Bypass Effect of Financial Globalization. American Economic Journal, 2, 173-204.

[9] Li, K.W. and Liu, J. (2012) How Does Financial Development Affect Bilateral Equity Capital Flows? World Economy, No. 8, 22-39.

[10] Chen, J.Q. and Zhang, Y. (2013) Study on Spillover Effects of Macroeconomic Policies in Major G20 Economies. World Economy Study, No. 8, 3-8.

[11] Zhang, H.Q. (2013) Policy Options for Loose Monetary Policy and Emerging Market Economies. International Finance Research, No. 10, 4-12.

[12] Yi, X.R. (2014) The Economic Analysis of the Exit of Quantitative Easing Monetary Policy by the Federal Reserve. International Finance Research, No. 1, 12-24.

[13] Zheng, X. (2015) Research on the Formation of Sudden Interruption of International Capital Flows in Emerging Market-Based on Information Asymmetry. Theory and Reform, 6, 81-84.

[14] Xiang, W.J. and Wang, D. (2011) The Impact of Changes in International Capital Flows on Emerging Market Countries-Based on Global Financial Crisis. International Finance Research, 7, 51-58.

[15] Zhang, M. and Xiao, L.S. (2014) The Influence Factors of International Capital Flows: The Comparison between Emerging Markets and Advanced Economies. World Economy, 8, 151-172.

[16] Zhang, G. (2016) The Influence Factors of Cross-Border Capital Flows in Emerging market-Empirical Analysis Based on Factor Analysis. World Economy Study, 10, $42-61+135-136$.

[17] Ma, Y. and Du, M. (2013) Influence Factors of International Capital Flows in Emerging Markets-Based on Dollar Factor and GMM Method. Economics of Finance and Trade, 1, 46-55.

[18] Wu, L. and Fu, G. (2014) RMB Exchange Rate, Short-Term Capital and Stock Price Interaction. Economic Research, 11, 72-86.

[19] Dong, Y. and Xie, Q. (2015) Research on the Impact of Exchange Rate Fluctuations on Capital Flows in Emerging Market Countries-Based on Quarterly Data from 23 Emerging Market Countries from 2000 to 2013. International Finance Research, 6, $42-52$.

[20] Zhao, X. and Liu, W. (2016) Financial Development and International Capital Flows: the Comparison between Emerging Markets and Advanced Economies. Economist, 6, 76-84.

[21] Arellano, M. and Bond, S. (1991) Some Tests of Specification for Panel Data: Monte Carlo Evidence and an Application to Employment Equation. Review of Economic Studies, 58, 277-297. https://doi.org/10.2307/2297968

[22] Arellano, M. and Bover, O. (1995) Another Look at the Instrumental Variables Estimation of Error Components Models. Journal of Economics, 68, 29-51. https://doi.org/10.1016/0304-4076(94)01642-D

[23] Blundell, R., Bond, S. and Windmeijer, F. (2000) Estimation in Dynamic Panel Data Models: Improving on the Performance of The Standard GMM Estimator. IFS 
Working WP00/12, Institute for Fiscal Studies.

[24] Cogley, T. and Sargent, T.J. (2001) Evolving Post-World War II U.S. Inflation Dynamics. NBER Macroeconomics Annual, 16, 331-373.

[25] Lubie, T.A. and Schorfheide, F. (2004) Testing for Indeterminacy: An Application to U.S. Monetary Policy. American Economic Review, 94, 190-219. https://doi.org/10.1257/000282804322970760

[26] Primiceri, G.E. (2005) Time Varying Structural Vector Autoregressions and Monetary Policy. Review of Economic Studies, 72, 821-852.

[27] Jouchi, N., Munehisa, K. and Toshiaki, W. (2009) Bayesian Analysis of Time-Varying Parameter Vector Autoregressive Model for the Japanese Economy and Monetary Policy. Discussion Paper.

[28] Jouchi, N. (2011) Time-Varying Parameter VAR Model with Stochastic Volatility: An Over-View of Methodology and Empirical Applications. Monetary and Economic Studies, 29, 107-142. 